\title{
Glucosinolates, myrosinase hydrolysis products, and flavonols found in rocket (Eruca sativa and Diplotaxis tenuifolia)
}

Article

Accepted Version

Bell, L. and Wagstaff, C. (2014) Glucosinolates, myrosinase hydrolysis products, and flavonols found in rocket (Eruca sativa and Diplotaxis tenuifolia). Journal of Agricultural and Food Chemistry, 62 (20). pp. 4481-4492. ISSN 0021-8561 doi: https://doi.org/10.1021/jf501096x Available at https://centaur.reading.ac.uk/37436/

It is advisable to refer to the publisher's version if you intend to cite from the work. See Guidance on citing.

Published version at: http://dx.doi.org/10.1021/j501096x

To link to this article DOI: http://dx.doi.org/10.1021/jf501096x

Publisher: American Chemical Society

All outputs in CentAUR are protected by Intellectual Property Rights law, including copyright law. Copyright and IPR is retained by the creators or other copyright holders. Terms and conditions for use of this material are defined in the End User Agreement.

www.reading.ac.uk/centaur 
Central Archive at the University of Reading

Reading's research outputs online 
Glucosinolates, myrosinase hydrolysis products and flavonols found in rocket (Eruca sativa and Diplotaxis tenuifolia)

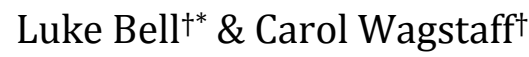

†Department of Food \& Nutritional Sciences and the Centre for Food Security, University of Reading, Whiteknights, Reading, Berkshire, UK. RG6 6AH

${ }^{*}$ Tel: +44(0) 7909447654

*Email: luke.bell@pgr.reading.ac.uk 


\section{Abstract}

2 Rocket species have been shown to have very high concentrations of glucosinolates and

3 flavonols, which have numerous positive health benefits with regular consumption. In this

4 review we highlight how breeders and processors of rocket species can utilize genomic and

5 phytochemical research to improve varieties and enhance the nutritive benefits to consumers.

6 Plant breeders are increasingly looking to new technologies such as HPLC, UPLC, LC-MS and

7 GC-MS to screen populations for their phytochemical content to inform plant selections. Here

8 we collate the research that has been conducted to-date in rocket, and summarise all

9 glucosinolate and flavonol compounds identified in the species. We emphasize the importance

10 of the broad screening of populations for phytochemicals and myrosinase degradation

11 products, as well as unique traits that may be found in underutilized gene bank resources. We

12 also stress that collaboration with industrial partners is becoming essential for long-term

13 plant breeding goals through research.

14 Key words: Brassicaceae, Isothiocyanates, Plant breeding, Indoles, Nitriles

15

16 
Introduction

27 In recent years, several species of minor leafy-crops have risen to prominence as potentially important commercial and edible species. One example is rocket, which has quickly gained popularity in the Western diet. Originally found as an obscure crop in Mediterranean and Middle-Eastern countries, rocket has become popular largely due to the pungent aromas and tastes associated with it. Glucosinolates (GSLs)/isothiocyanates (ITCs) and flavonols derived from many species ${ }^{1-4}$ have been shown to infer significant protection against cancer and heart disease ${ }^{4-11}$. In Western countries, diets are generally lacking in fruits and vegetables. Despite government initiatives (such as the "5-a-day" campaign in the UK and USA), these diseases are increasingly leading to premature deaths ${ }^{12}$. Plant breeders aim to maximize levels of such beneficial compounds, but with little genomic information about rocket species presently available, this is a formidable task. This review will give an overview of research in rocket, an outbreeding crop, and how breeders and processors can utilize it to enhance beneficial compounds.

\section{Rocket species}

41 Rocket (also known as arugula, rucola and roquette) is a leafy vegetable crop that has gained substantial popularity across the world, particularly over the last fifteen years ${ }^{13-16}$. Two main species are predominantly farmed as salad crops; these are Eruca sativa ('salad' or 'cultivated' rocket; sometimes referred to as Eruca vesicaria subsp. sativa) and Diplotaxis tenuifolia ('wild' rocket). Both species share a peppery taste and aroma that is very distinctive ${ }^{17}$. They have been reported to contain high levels of vitamin C, GSLs, flavonols and phenolics ${ }^{18-25}$. These are all known to have both anti-oxidant and anti-cancer properties, and are also implicated in lowering the risk of cardiovascular and cognitive disease. For excellent information on these beneficial effects and their underlying causes, see Drewnowski \& Gomez-Carneros ${ }^{26}$, Keum 
et.al ${ }^{27}$, D’Antuono et.al ${ }^{28}$, Egea-Gilbert et.al ${ }^{29}$, Degl'Innoocenti et.al ${ }^{30}$, Bjorkman et.al ${ }^{31}$ and

51 Jeffery et.al ${ }^{32}$.

Taxonomy and domestication

A distinction should be made that both Eruca and Diplotaxis species have overlapping characteristics, and that one can be easily mistaken for the other by the untrained eye, and/or before a certain level of maturity has been reached ${ }^{28}$. It is also arguable that D. tenuifolia is the least 'wild' of the two species even though the common name is 'wild rocket'. It is featured and favored in commercial products and breeding programs, and is likely to be more domesticated than Eruca species as a result. Diplotaxis varieties are generally uniform phenotypically, with Eruca varieties being more diverse in this respect ${ }^{23}$. No direct genomic evidence has been presented in the literature to suggest one species is any more or less genetically variable than the other. Variability in GSL data seems to support the hypothesis that Diplotaxis species are more 'wild' 33 , though it is not conclusive, as only a relatively small number of cultivars have been tested. This is a point that needs clarification through research and extensive breeding, as neither species can be considered fully domesticated ${ }^{29}$. For example, germination rates are variable, reproductive organs are typically small, seedpods shatter and disperse freely (rather than staying on the plant), and physical defenses such as leaf hairs are still present in many commercial varieties ${ }^{34}$.

\section{Phytochemicals in Eruca sativa and Diplotaxis tenuifolia: types and structures}

\section{Glucosinolates}

71 GSLs are $\beta$-thioglucoside $N$-hydrosulphates that are responsible for the sharp and bitter-

72 tasting flavors found in cruciferous vegetables 35,36. In combination with the enzyme 73 myrosinase (thioglucoside glucohydrolase, EC 3.2.1.147), GSLs are hydrolyzed to create 74 isothiocyanates, nitriles, thiocyanates, epithionitriles, indoles, oxazolidine-2-thiones, 
cyanopithioalkanes, ascorbigens, goitrogens and epithioalkanes ${ }^{37-49}$; see Figure 1 . Many of these hydrolysis products have antibacterial, antifungal and insect repellant effects ${ }^{50-55}$. GSLs and ITCs are being increasingly used as 'biofumigants' to suppress soil borne pathogens, nematodes and weeds. Some of the volatile products have the opposite effect of attracting species that can tolerate high GSL concentrations, such as types of ovipositing insect 56,57 .

The conditions under which hydrolysis of GSLs occurs will affect the respective proportions of the chemicals produced; $\mathrm{pH}$, iron ions, thiol ions, temperature and hydration play a particularly prominent role in this process in vivo ${ }^{58}$. The separation of GSLs in specialist 'S-cells' from myrosinase in myrosin cells means that the two components only come into contact upon tissue disruption; for example when damaged via chewing or digestion ${ }^{59-69}$. It is the biological activity of the ITC hydrolysis products in humans that are of most interest in rocket ${ }^{50}$. GSLs can be hydrolyzed within the intestinal tract by gut microflora that are known to have specific myrosinase activity ${ }^{70-73}$, but the efficacy of their action is not yet well determined. conditions and stress ${ }^{7}$. Other factors affecting GSL profiles include the plant age, organ type, developmental stage, ambient air temperature, level of water stress, photoperiod, agronomic practice, degree of wounding, and geographical origin of the variety/species ${ }^{74-81}$. These can often affect the profiles of all phytonutrients contained within tissue, not just GSLs ${ }^{82}$, and they are all factors that plant breeders aim to mitigate through development of genetically advanced and uniform breeding lines.

GSLs and the ITC derivatives have been an integral part of the human diet for millennia because of the presence of them in the family Brassicaceae $64-66,83-89$. GSLs are evolutionarily recent secondary metabolic products having arisen 10-15 million years ago 90,91, acting to prevent pathogen attack and dissuade herbivory. They are known in only a few angiosperm 
100 families of the order Brassicales, which includes the Brassicaceae ${ }^{92-100}$, and of which Eruca 101 and Diplotaxis are members.

102 A study by Pasini et al. 33 of 37 rocket accessions (Diplotaxis and Eruca) showed that 103 GSL profiles were all very similar, regardless of the species. In total, twelve GSL compounds 104 were found across all accessions; Table 1 illustrates all known GSL compounds identified to105 date in rocket. These include 4-mercaptobutyl GSL (glucosativin) 21, 4-methylthiobutyl GSL 106 (glucoerucin) 101, and 4-methylsulfinylbutyl GSL (glucoraphanin) 28 , which constitute the 107 three most abundant GSLs in rocket.

\section{Flavonols}

109 Flavonols are diphenylpropanes $\left(\mathrm{C}_{6}-\mathrm{C}_{3}-\mathrm{C}_{6}\right){ }^{102}$ and are another important group of chemicals 110 found within rocket species. Flavonols in rocket are found with sugar conjugates, and 111 typically occur in relatively large quantities ${ }^{103}$. The aglycones found (such as quercetin and 112 kaempferol) are glycosylated and acylated, which in turn affects their biological properties 18. 113 A study by Martínez-Sánchez et al. 18 identified over 50 different flavonol compounds across 114 four different species. Watercress, mizuna and two species of rocket were all found to 115 accumulate very different compounds within their leaves, and in varying quantities. Wild 116 rocket showed high levels of quercetin-3,3',4-triglucosyl (43.5 mg per $100 \mathrm{~g}^{-1} \mathrm{fw}$ ) and salad 117 rocket had mostly kaempferol-3,4'-diglucosyl (97.8mg per $\left.100 \mathrm{~g}^{-1} \mathrm{fw}\right)$. The group also showed 118 a correlation between quercetin derivatives and high antioxidant activity, despite the 119 significant variations seen between species.

Studies conducted on rocket tissues have identified significant concentrations of

121 polyglycosylated flavonols. The core aglycones of these are kaempferol, quercetin and 122 isorhamnetin 102; Table 2 provides an up-to-date list of all flavonol compounds identified in 123 rocket to-date. Martinez-Sanchez et al. ${ }^{18}$ showed that Eruca species accumulate kaempferol 124 derivatives, whereas $D$. tenuifolia accumulates predominantly quercetin instead, meaning that 
125 the two chemicals could be used as an identification marker between the two species 104.

126 Isorhamnetin aglycones are common to both species but typically in much lower 127 concentrations ${ }^{33}$. The specific aglycones also infer varying degrees of anti-oxidant activity. 128 For example, quercetin derivatives have a higher activity than kaempferol and isorhamnetin. 129 The differences in structure (the arrangement of hydroxyl groups and glycosylation) affect 130 anti-oxidant activity by allowing the molecules to act as hydrogen/electron donors, single 131 oxygen scavengers, or as reducing agents 105.

\section{Phytochemicals and the relation with quality: taste and aroma}

134 It is thought that the presence of glucosativin, glucoerucin and their hydrolysis products 135 within rocket leaves is what gives them a characteristic flavor ${ }^{44}$. Many of the health beneficial 136 GSLs and ITCs are thought to be responsible for strong tastes that some consumers find 137 repellant 106 . It seems that to many people, these compounds contribute very little to a 138 pleasurable eating experience and are actively avoided ${ }^{83}$. Conversely however, some people 139 do prefer these strong tastes and aromas, and will actively seek to consume rocket when it is 140 available. Growers in Italy often prefer the subsequent cuts because of the more intense tastes 141 and aromas that are produced 107 and some will even 'sacrifice' the first cut in favour of the 142 subsequent leaf growth. This highlights a divide between consumers that may be indicative of 143 underlying genotype(s) for taste perception and preference.

144 The breeding process in rocket varieties to-date has effectively made the species 145 'milder' in taste when compared to plants that grow naturally in the wild. Whether this has 146 been intentional or as a result of selecting for other unrelated traits (such as leaf morphology) 147 is debatable. Some recent commercial varieties have been bred for a 'hotter' taste, such as 148 'Wildfire', by Tozer Seeds (Surrey, UK). 
A study by Pasini et al. ${ }^{17}$ demonstrated how breeding for sensory traits could be 150 achieved, by highlighting which glucosinolates contributed to specific taste and aroma 151 elements in rocket. It was found that progoitrin/epiprogoitrin is responsible for bitter taste 152 attributes, despite being only a minor component of the overall GSL profile of rocket (4.3$15311.4 \%$ of total GSL concentration). The perceived pungency of leaves was positively related to 154 the overall GSL content of accessions, and the levels of glucoraphanin negatively contributed to the typical 'rocket' flavour. The study also highlighted an important difference between rocket and other Brassica sensory studies ${ }^{108}$, in that bitterness was perceived as a favorable 157 characteristic according to panelists. The flavonol compound kaempferol-3-(2-sinapoyl158 glucoside)-4'-glucoside also significantly and positively contributed to flavor attributes in 159 Eruca accessions. This would indicate that GSL compounds are not totally responsible for 160 flavor in rocket. The study itself stopped short of saying how or if the information obtained 161 would be used in breeding programs, but with study into rocket flavor components, milder 162 (and/or stronger) varieties could be bred more efficiently once the responsible compounds 163 are properly identified ${ }^{26}$.

Health promoting properties of glucosinolate-myrosinase products and flavonols of rocket

\section{Isothiocyanates}

168 ITC hydrolysis products have been identified in rocket 45 , such as 4-(methylthio)butyl ITC 169 (erucin) 109,110 which is known to show anti-proliferative activity in human lung carcinoma 170 A549 cells, hepatoma (HepG2) cells, colon cancer cells, prostate cancer cell lines (PC3, BPH-1 171 and LnCap) and leukemia cells ${ }^{111}$. Erucin is a structurally reduced analog of sulforaphane, 172 (which is predominantly found in broccoli) and has shown promising anti-cancer properties 173 in vitro (e.g. anti-proliferation of human erytroleukemic K562 cells) ${ }^{112}$. Research into the 
174 chemopreventative and anti-genotoxic nature of ITCs has shown promising results ${ }^{113}$ (see

175 Figure 2). Other studies involving chemically induced genotoxicity have shown very strong 176 anti-genotoxic effects of E. sativa extracts ${ }^{13}$ which is in agreement with other Brassicaceae 177 studies 114,115. Identifying specific cultivars of rocket with elevated levels of erucin and 178 glucoraphanin would be an important first-step in developing superior varieties from a 179 human nutrition standpoint.

The results of GSL/ITC research prompted an investment in broccoli breeding in the 181 last decade. A similar concerted effort could be made for rocket which contains similar 182 compounds, and which are potentially just as efficacious in humans ${ }^{116}$. Erucin for example, 183 has been shown to have very similar, and even superior, biological activity to sulforaphane ${ }^{117}$. 184 One paper has specifically demonstrated that the concentrations of rocket ingested in an 185 average daily diet is significant enough to infer a cancer preventative effect 13 . The 186 metabolism of ITCs in humans via the mercapturic acid pathway has been investigated. ITCs 187 are conjugated with glutathione and degraded by $\mathrm{N}$-acetylation, initiating an increase of phase 188 II detoxification enzymes; see Figure 3 for detailed pathway breakdown of erucin ${ }^{113}$.

\section{Nitriles}

190 Along with ITCs, nitriles are the most abundant bioactive compounds produced by GSL 191 hydrolysis 116. The hydrolysis of glucoraphanin for example, yields predominantly 192 sulforaphane and sulforaphane nitrile. The ratio in which the two are formed depends greatly 193 upon the environmental conditions and the plant cultivar that is used ${ }^{117}$. A low pH medium 194 tends towards the formation of nitriles, whereas high $\mathrm{pH}$ forms ITCs 118,119 . The presence of 195 thiol and iron ions favors nitriles, and high temperature and hydration produce more ITCs 196 120,121. This can have substantial consequences for any potential health benefits that might be 197 inferred from eating rocket ${ }^{119}$. The nitrile form is approximately three orders of magnitude 198 less efficacious than the ITC in inducing quinone reductase (phase II enzyme), and thus infers 
a reduced enzymatic and anticarcinogenic response. Nitriles also compete with ITCs in this 200 induction, and reduce potential positive effects further ${ }^{38}$. As the ratio of these compounds 201 may depend on plant variety, care must be taken in rocket breeding when selecting plants for 202 GSL content, as this may not be reflective of the bioactives produced in subsequent hydrolysis 203 reactions ${ }^{122}$. Other underlying genetic factors may influence which degradation pathway is 204 taken.

\section{Indoles}

206 Indoles are the predominant autolysis product of indole glucosinolates such as glucobrassicin, 207 as their ITC counterparts are unstable ${ }^{85}$. Glucobrassicin has been detected as a minor GSL in 208 rocket species ${ }^{33}$, and the predominant indole species produced is indole-3-carbinol. This 209 compound is known to be cancer-preventative 125,126 , particularly in reproductive organs in 210 vitro and in vivo. A condensation product of indole-3-carbinol, 3,3'-diindolymethane, is also 211 responsible for beneficial physiological effects. Both compounds have been shown to reduce 212 cell proliferation in breast, prostate, cervical and colon cancer cell lines. They also show 213 distinct differences from ITCs such as sulforaphane ${ }^{127}$, and inhibition of tumor development 214 in the stomach, breast, uterus, tongue and liver of rodents ${ }^{128-135}$. Experiments in rodents have 215 shown an increase in drug-metabolizing enzymes in the stomach, liver and small intestines of 216 individuals consuming both ITCs and indoles. This is suggestive of enhanced detoxification 217 phase II enzymes (such as quinone reductase, glutathione reductase and glutathione 218 transferase) ${ }^{134}$, and a mechanism by which these phytochemicals infer chemopreventative 219 effects $135,136$.

Typically indoles inhibit cell proliferation through cytostatic mechanisms, whereas 221 ITCs induce cytotoxicity within cell lines (at above $12.5 \mu \mathrm{M}$ concentrations), which ultimately 222 leads to increased apoptosis 137,138. This indicates that both types of compound could act and 223 be effective at different stages of cancer development ${ }^{11}$. Indoles have been shown to induce 
224 programmed cell death in prostate, breast and osteocarcinoma cell lines ${ }^{139}$ and $\mathrm{G}_{1}$ cell cycle 225 arrest in breast and prostate cancer cell lines 142,143 . It is these cytostatic effects on cell 226 proliferation that has been suggested as the mechanism responsible for the lack of apoptosis 227 effects in indoles ${ }^{141}$.

Using information on GSL content in rocket, the ITC and indole effects can be 229 potentially maximized in new varieties, and be of a greater benefit to human health when 230 considered in tandem, rather than separately 127.

\section{Oxazolidine-2-thiones \& goitrogens}

232 The hydrolysis of $\beta$-hydroxy-alkyl GSL compounds (e.g. progoitrin; a minor GSL in rocket) can 233 produce oxazolidine-2-thiones such as goitrin (5-vinyloxazolidine-2-thione) ${ }^{142-148}$. It is these 234 compounds that are largely attributed to the thyroid condition of goiter in mammals ${ }^{149}$, but 235 the action of microflora in the gut is thought to mediate the problems associated with high 236 oxazolidine-2-thione intake 150,151. That being said, oxazolidine-2-thiones interfere with 237 thyroxine synthesis 154 and are therefore likely to have an adverse biological effect regardless 238 of gut microflora action or bodily iodine status ${ }^{3}$. A study by Nishie and Daxenbilcher 155 239 showed that these compounds are not teratogenic or embryotoxic however.

These molecules contribute significantly to the bitter taste of rocket that some people 241 perceive quite strongly ${ }^{154}$. The detection of these compounds may be mediated in a similar 242 genetic fashion as PROP (propylthiouracil), for example 155,156. By using phytochemical data in 243 rocket breeding programs these oxazolidine-2-thione components could be reduced, 244 potentially improving consumer acceptance (depending on the target consumer) and avoiding 245 any possible adverse health effects associated with over-consumption.

\section{Ascorbigens}

247 Ascorbigens are formed via the reaction of indole-3-carbinol and 3,3'-diindolymethane with 248 ascorbic acid in the stomach during myrosinase-catalyzed degradation of indoly-3methyl 
249 glucosinolates 157,158 . In this manner it is thought that ascorbigens have a role in cancer250 modulation ${ }^{159}$ via quinone reductase induction ${ }^{114}$. As has been highlighted previously, this 251 has important implications for breeding for plant varieties with enhanced chemopreventative 252 effects.

\section{Epithioalkanes}

254 Epithioalkanes are formed as part of the myrosinase reaction with GSLs at low pH with epithiospecifier protein and ferrous ions. These GSLs typically have a side-chain with a double bond, such as sinigrin 160,161 . It is uncertain whether these compounds produce any significant

257 bioactive effect in humans, but the ratio in which they are produced alongside ITCs, nitriles 258 and indoles may impact on these compounds' efficacy as anti-carcinogens.

\section{Flavonols}

260 The antioxidant and anti-inflammatory function of flavonols in the human diet are well known 261 and include protecting the colonic epithelium from free radical damage $164-167$. They can 262 induce the up-regulation of enzymes (such as cytochrome P450), that may lead to a decreased 263 risk of cancer, cardiovascular disease, immune dysfunction, atherosclerosis and chronic 264 inflammation $168,169$.

\section{Factors affecting phytochemical content}

267 Breeding and cultivation

268 Rocket has been consistently shown to be a good dietary source for flavonols, GSLs and anti269 oxidants. However, there can be large differences between plants of the same germplasm 270 accession due to a combination of genetic and environmental variability. This is probably due 271 to the outbreeding nature of the species ${ }^{104}$ and a lack of overall uniformity in varieties. 272 Commercial varieties cannot be considered truly domesticated because of this tendency for 273 outcrossing, and the susceptibility of plants to inbreeding depression (a loss of genetic 
274 variability due to repeated self-pollination or crossing with a closely related individual). 275 Development of advanced open-pollinating breeding lines (lines that are allowed to cross276 pollinate freely in a population of selected individuals), or even $\mathrm{F}_{1}$ hybrids (superior varieties 277 produced by crossing distinctly different, elite inbred lines), could potentially minimize such 278 variation.

Throughout the food chain there are many aspects that can have an adverse effect on 280 GSL levels within leaves (Figure 4). These include the cultivar choice, cultivation practice, 281 climatic conditions, photoperiod, sulphur and nitrogen availability, harvest date, time spent in 282 storage, the temperature of wash water, levels of physical damage to leaves, packaging 283 atmosphere and food preparation methods ${ }^{30-32,170-173 .}$

\section{Harvesting}

285 Rocket species have the ability to re-grow their leaves repeatedly after cutting, which allows 286 for several harvests to take place under optimal conditions ${ }^{107}$. In parts of southern Italy, it is 287 not unheard of for up to seven harvests to occur from a single planting. This has obvious cost288 saving benefits for growers, but multiple harvests also induce stress responses in rocket that 289 may be detrimental to the flavor and aesthetics of the crop. Stress drives up the production of 290 secondary metabolites such as GSLs and anthocyanins, which will produce very strong, bitter 291 tastes. There are other detrimental effects of multiple harvests; leaves become progressively 292 smaller and more 'skeletal' in appearance with each cutting, for example. High anthocyanin 293 levels also affect the color of leaves, turning them an undesirable pink, purple or red. Color 294 has been found to be one of the most important characteristics consumers look for in rocket 295174 , and so the loss of fresh appearance can ultimately lead to rejection of crops by 296 supermarkets and processors.

297 Industrial and culinary processing 
298 There are five main influences that have been identified in affecting GSL levels during 299 processing ${ }^{94}$. These are the action of myrosinase hydrolysis, myrosinase inactivation, the 300 lysis and leaching of GSLs into wash-water, thermal degradation of GSLs, and the loss of 301 ascorbic acid, iron and other enzyme co-factors. Myrosinase inactivation and thermal 302 degradation of GSLs is probably less of an issue in rocket species, as the leaves are not 303 typically cooked. The leaves are not ordinarily frozen, and so freeze-thaw hydrolysis is not 304 likely to be a major factor either. Other factors almost certainly play a significant role in GSL 305 and phytochemical loss in rocket. Verkerk et al. ${ }^{94}$ highlighted four key areas that affect GSL 306 levels before reaching the end consumer. These are:

307 1. The variety / cultivar used

308 2. Storage and packaging (post-harvest, post-processing \& in shops/supermarkets)

$309 \quad 3$. Industrial processing

310 4. Consumer preparation methods

311 If each of these areas can be mitigated through breeding superior varieties, consumers 312 will receive an end product that is of higher nutritive quality and thus provide increased 313 health benefits.

\section{Post harvest storage}

315 Studies on both Diplotaxis and Eruca species have been conducted to determine the effects of 316 post harvest storage conditions on chlorophyll content and respiration rates ${ }^{15}$. Both species 317 of rocket have been found to have high respiration rates ${ }^{107}$ leading to rapidly impaired visual 318 quality, such as stem browning, tissue yellowing and general decay ${ }^{175}$. Provided initial GSL 319 loss can be mitigated through breeding, ITC formation has been shown to increase over nitrile 320 formation during the storage period ${ }^{176}$.

Time, temperature, humidity and atmospheric conditions are all optimized for specific 322 crops within the logistics chain, but these factors are often only designed to prevent visual 
323 degradation and not phytochemical breakdown ${ }^{100}$. Getting producers, packagers and 324 transporters to change their current practices in order to better preserve the health325 promoting compounds in rocket would be a difficult task. Treatments and storage conditions 326 are often integrated parts of protocols and procedures, and changing these would require 327 significant testing on a commercial scale.

\section{New selection tools for breeders}

\section{Phytochemical selection}

331 It should not be forgotten that some GSLs and their breakdown products are thought to be 332 toxic, and even carcinogenic, at high concentrations ${ }^{128}$. Breeders and researchers should be 333 mindful that more of a certain compound does not necessarily mean 'better' ${ }^{177}$. Humans seem 334 to be able to tolerate GSLs much better than pigs, rats and rabbits for example; but 335 overconsumption of these compounds may have serious health consequences ${ }^{64}$ as high dose336 effect relationships are as yet unknown in humans ${ }^{94}$. Few papers in GSL research (regardless 337 of species) have acknowledged the potential for plant breeders to utilize HPLC/UPLC/LC338 MS/GC-MS methods within breeding programs to 'monitor' and select plants for their 339 phytochemical content in this manner. These techniques would provide valuable information 340 on breeding lines relatively rapidly, especially for GSL and flavonol breeding ${ }^{178}$. It is not

341 common practice to select rocket plants based on their phytochemical profile at present, but 342 as interest in these compounds increases it will be necessary for breeders to modify their 343 selection criteria and information sources in order to remain competitive in the salad 344 vegetable market ${ }^{94}$. This has been achieved with 'Beneforte' broccoli (Seminis Vegetable 345 Seeds; subsidiary of Monsanto Company, St. Louis, Missouri, USA; www.beneforte.com) for example. It has also been indicated in hybrid varieties of Brassica that ITC/nitrile ratios can be 347 selected for ${ }^{179}$. 


\section{Genetic resources and Marker Assisted Breeding}

European initiatives (such as the EU GENRES project 'Leafy vegetables germplasm, stimulating use'; http://documents.plant.wur.nl/cgn/pgr/leafyveg/) have included rocket species within their remit, indicating the rising prominence of the species, and the desire for more work to be conducted on them. The germplasm accessions stored in gene banks are a valuable genetic resource for breeders to take advantage of ${ }^{180}$. The accessions contained within these collections are highly variable and have unique visual and sensory characteristics that could be introgressed into breeding lines relatively easily 181 .

Genetic information about rocket within the published literature is very scarce. Some molecular marker techniques such as Random Amplification of Polymorphic DNA (RAPD), Inter-Simple Sequence Repeats (ISSR) and Amplified Fragment Length Polymorphisms (AFLP) have been used to analyze morphological characteristics of Eruca vesicaria ${ }^{29}$. ISSR and AFLP are relatively robust for screening variable populations and discriminating between cultivars 180 but RAPDs are notoriously unreliable and suffer from a lack of reproducibility and resolution. Perhaps one of the most underutilized marker types is SRAP (Sequence Related Amplified Polymorphism). The forward and reverse primers are designed to target arbitrary GC and AT rich sequences of the genome respectively, and are therefore more likely to anneal to active genomic regions ${ }^{182}$. This could be of use in understudied crops such as rocket, as it provides a simple, repeatable and reliable way of screening large populations.

These techniques are now for the most part however, obsolete in advanced molecular plant breeding, as NGS (Next Generation Sequencing) and SNP (Single Nucleotide Polymorphism)/QTL (Quantitative Trait Loci) analyses are far more specific, reliable and cost-effective. SNPs are the most abundant marker type within genomes, and their high density is ideal for studying specific regions in detail ${ }^{183}$. NGS techniques are now relatively affordable, even for relatively small companies. They are widely available in academic 
373 institutions, but many companies are bypassing these in favor of dedicated private 374 commercial services ${ }^{184}$ or are developing their own in-house facilities. The inability of some 375 research institutions to provide adequate customer service, cost-effectiveness, data storage, 376 and results on time is jeopardizing how much knowledge is in the public domain. Increasingly, 377 both large and small breeding companies are collaborating privately and advancing 378 techniques far beyond those found in academic institutions. Future work by institutes in 379 advanced genomics, sequencing and genotyping is likely to be obsolete in some cases because 380 private research is already finding new innovations, e.g. for data storage and bioinformatics. 381 Because private companies have no obligation to share their knowledge, many of these 382 advances may be unobserved by the mainstream scientific community. Institutes and 383 Universities need to do more to attract business from industry in order to keep up with the 384 pace of private advances in this area.

Transcriptome sequences are now (generally) adequate for breeders to use and make 386 huge advances in only a few years. Linkage mapping and QTL analyses can be conducted on 387 desktop computers, making integration into breeding companies relatively straightforward 388 from an IT point of view, even if the actual sequencing and genotyping are outsourced. Again, 389 this may typically be to private companies providing a dedicated service. The availability of 390 software licenses and advanced training courses from private companies also means plant 391 breeders do not necessarily need the expertise found in Universities and research institutes in 392 order to attain their goals.

394 Summary

395 Of all the research papers concerning rocket species and their phytochemistry, none have 396 directly addressed how information could be used within a working breeding population. 397 Often it is explained or postulated purely as theory rather than actual practice, or only given a 
cursory mention. Only very rarely is a plant breeding program reflective of theory, due to the

399 large number of environmental factors affecting plant growth, development and reproduction.

400 The progressive selection of rocket plants through conventional/molecular breeding would

401 be a valuable tool for the research community as well as providing an excellent incentive for 402 breeding companies to fund research. The actual monitoring and quantification of 403 GSL/flavonol levels through successive generations (i.e. not just one as has been the case with 404 most studies) would not only validate the heritability of such traits in rocket, but would also 405 provide a 'roadmap' for how other minor crops might be developed for commercial use.

Attention must be paid to the phytochemical content of varieties within breeding 407 populations of rocket. By focusing solely on morphological traits, important phytochemical 408 genotypes may be inadvertently lost from populations; this could be said of all Brassicaceae 409 species, not just rocket. The balance of glucosinolate-myrosinase degradation products does 410 seem to have a genetic component to it and so could be selected for also. Utilising genetic 411 resources, the falling costs of sequencing and bioinformatics can produce nutritively superior 412 varieties of rocket in the near future. Plant breeding typically takes longer than the average 413 research project allows for, even with the use of advanced genomic selection methods. This is 414 a situation that could be remedied by long-term industrial collaboration and sponsorship by 415 plant breeding firms.

\section{References}

(1) Chaudhary, A.; Rampal, G.; Sharma, U.; Thind, T. S.; Singh, B.; Vig, A. P.; Arora, S. Med. Chem. Drug Discov. 2012, 2, 30-37.

420 (2) Gross, H. B.; Dalebout, T.; Grubb, C. D.; Abel, S. Plant Sci. 2000, 159, 265-272.

421 (3) Jongen, W. M. F. Proc. Nutr. Soc. 1996, 55, 433-446.

422 (4) Vinson, J. A.; Dabbagh, Y. A.; Serry, M. M.; Jang, J. H. J. Agric. Food Chem. 1995, 43, 28002802.

424 (5) Clarke, J. D.; Dashwood, R. H.; Ho, E. Cancer Lett. 2008, 269, 291-304. 
425 (6) Hayes, J. D.; Kelleher, M. O.; Eggleston, I. M. Eur. J. Nutr. 2008, 47, 73-88.

426 (7) Herr, I.; Buechler, M. W. Cancer Treat. Rev. 2010, 36, 377-383.

427 (8) Melchini, A.; Traka, M. H. Toxins (Basel). 2010, 2, 593-612.

428 (9) Zhang, Y. S. Mutat. Res. Mol. Mech. Mutagen. 2004, 555, 173-190.

(10) Yang, Y. M.; Conaway, C. C.; Chiao, J. W.; Wang, C. X.; Amin, S.; Whysner, J.; Dai, W.; Reinhardt, J.; Chung, F. L. Cancer Res. 2002, 62, 2-7.

(11) Pappa, G.; Lichtenberg, M.; Iori, R.; Barillari, J.; Bartsch, H.; Gerhauser, C. Mutat. Res. Mol. Mech. Mutagen. 2006, 599, 76-87.

(12) Casagrande, S. S.; Wang, Y.; Anderson, C.; Gary, T. L. Am. J. Prev. Med. 2007, 32, 257-263.

(13) Lamy, E.; Schroder, J.; Paulus, S.; Brenk, P.; Stahl, T.; Mersch-Sundermann, V. Food Chem. Toxicol. 2008, 46, 2415-2421.

(14) D’Antuono, L. F.; Elementi, S.; Neri, R. J. Sci. Food Agric. 2009, 89, 713-722.

(15) Koukounaras, A.; Siomos, A. S.; Sfakiotakis, E. Postharvest Biol. Technol. 2007, 46, 167173.

(16) Hall, M. K. D.; Jobling, J. J.; Rogers, G. S. Veg. Crop. Res. Bull. 2012, 76, 21-41.

(17) Pasini, F.; Verardo, V.; Cerretani, L.; Caboni, M. F.; D’Antuono, L. F. J. Sci. Food Agric. 2011, 91, 2858-2864.

(18) Martinez-Sanchez, A.; Gil-Izquierdo, A.; Gil, M. I.; Ferreres, F. J. Agric. Food Chem. 2008, 56, 2330-2340.

(19) Kim, S. J.; Ishii, G. J. Sci. Food Agric. 2007, 87, 966-973.

(20) Bennett, R. N.; Carvalho, R.; Mellon, F. A.; Eagles, J.; Rosa, E. A. S. J. Agric. Food Chem. 2007, 55, 67-74.

(21) Bennett, R. N.; Mellon, F. A.; Botting, N. P.; Eagles, J.; Rosa, E. A. S.; Williamson, G. Phytochemistry 2002, 61, 25-30.

(22) Cataldi, T. R. I.; Rubino, A.; Lelario, F.; Bufo, S. A. Rapid Commun. Mass Spectrom. 2007, $21,2374-2388$.

(23) Bennett, R. N.; Rosa, E. A. S.; Mellon, F. A.; Kroon, P. A. J. Agric. Food Chem. 2006, 54, 4005-4015.

(24) Chun Arasu, M.V., Lim, Y-P., Kim, S-J., J.-H. Hortic. Environ. Biotechnol. 2013, 54, 206213. 
(25) Martinez-Sanchez, A.; Llorach, R.; Gil, M. I.; Ferreres, F. J. Agric. Food Chem. 2007, 55, 1356-1363.

(26) Drewnowski, A.; Gomez-Carneros, C. Am. J. Clin. Nutr. 2000, 72, 1424-1435.

(27) Keum, Y. S.; Jeong, W. S.; Kong, A. N. T. Mutat. Res. Mol. Mech. Mutagen. 2004, 555, 191202.

(28) D’Antuono, L. F.; Elementi, S.; Neri, R. Phytochemistry 2008, 69, 187-199.

(29) Egea-Gilabert, C.; Fernandez, J. A.; Migliaro, D.; Martinez-Sanchez, J. J.; Vicente, M. J. Sci. Hortic. (Amsterdam). 2009, 121, 260-266.

(30) Degl'Innoocenti, E.; Pardossi, A.; Tattini, M.; Guidi, L. J. Food Biochem. 2008, 32, 642653.

(31) Bjorkman, M.; Klingen, I.; Birch, A. N. E.; Bones, A. M.; Bruce, T. J. A.; Johansen, T. J.; Meadow, R.; Molmann, J.; Seljasen, R.; Smart, L. E.; Stewart, D. Phytochemistry 2011, 72, 538-556.

(32) Jeffery, E. H.; Brown, A. F.; Kurilich, A. C.; Keck, A. S.; Matusheski, N.; Klein, B. P.; Juvik, J. A. J. Food Compos. Anal. 2003, 16, 323-330.

(33) Pasini, F.; Verardo, V.; Caboni, M. F.; D’Antuono, L. F. Food Chem. 2012, 133, 1025-1033.

(34) Gepts, P. What is a crop?: The Domestication Syndrome. http://www.plantsciences.ucdavis.edu/gepts/pb143/LEC16/Pb143116.htm

(35) Rungapamestry, V.; Duncan, A. J.; Fuller, Z.; Ratcliffe, B. Proc. Nutr. Soc. 2007, 66, 69-81.

(36) Velasco, P.; Cartea, M. E.; Gonzalez, C.; Vilar, M.; Ordas, A. J. Agric. Food Chem. 2007, 55, 955-962.

(37) Hecht, S. S. J. Nutr. 1999, 129, 768S-774S.

(38) Matusheski, N. V; Jeffery, E. H. J. Agric. Food Chem. 2001, 49, 5743-5749.

(39) Rangkadilok, N.; Nicolas, M. E.; Bennett, R. N.; Premier, R. R.; Eagling, D. R.; Taylor, P. W. J. Sci. Hortic. (Amsterdam). 2002, 96, 27-41.

(40) Yuan, G. F.; Sun, B.; Yuan, J.; Wang, Q. M. J. Zhejiang Univ. B 2009, 10, 580-588.

(41) Jia, C. G.; Xu, C. J.; Wei, J.; Yuan, J.; Yuan, G. F.; Wang, B. L.; Wang, Q. M. Food Chem. 2009, $114,28-37$.

(42) McNaughton, S. A.; Marks, G. C. Br. J. Nutr. 2003, 90, 687-697.

(43) Zhang, Y. S.; Talalay, P.; Cho, C. G.; Posner, G. H. Proc. Natl. Acad. Sci. U. S. A. 1992, 89, 2399-2403. 
(44) Bones, A. M.; Rossiter, J. T. Phytochemistry 2006, 67, 1053-1067.

(45) Jirovetz, L.; Smith, D.; Buchbauer, G. J. Agric. Food Chem. 2002, 50, 4643-4646.

(46) Grubb, C. D.; Abel, S. Trends Plant Sci. 2006, 11, 89-100.

489 (47) Yan, X. F.; Chen, S. X. Planta 2007, 226, 1343-1352.

(48) Baik, H. Y.; Juvik, J.; Jeffery, E. H.; Wallig, M. A.; Kushad, M.; Klein, B. P. J. Food Sci. 2003, 68, 1043-1050.

(49) Taiz, L.; Zeiger, E. Plant physiology; 4th ed.; Sinauer: Sunderland, Mass, 2006; p. xxvi, $764 \mathrm{p}$.

(50) Halkier, B. A.; Gershenzon, J. In Annual Review of Plant Biology; 2006; Vol. 57, pp. 303333.

(51) Mithen, R.; Campos, H. Entomol. Exp. Appl. 1996, 80, 202-205.

(52) Newman, R. M.; Hanscom, Z.; Kerfoot, W. C. Oecologia 1992, 92, 1-7.

498

(53) Ostrofsky, M. L.; Zettler, E. R. J. Ecol. 1986, 74, 279-287.

(54) Jeffries, M. Freshw. Biol. 1990, 23, 265-269.

(55) Newman, R. M.; Kerfoot, W. C.; Hanscom, Z. J. Chem. Ecol. 1990, 16, 245-259.

(56) Brown, P. D.; Morra, M. J. J. Agric. Food Chem. 1995, 43, 3070-3074.

(57) Vaughn, S. F.; Isbell, T. A.; Weisleder, D.; Berhow, M. A. J. Chem. Ecol. 2005, 31, 167-177.

(58) Foo, H. L.; Gronning, L. M.; Goodenough, L.; Bones, A. M.; Danielsen, B. E.; Whiting, D. A.; Rossiter, J. T. FEBS Lett. 2000, 468, 243-246.

(59) Song, L.; Thornalley, P. J. Food Chem. Toxicol. 2007, 45, 216-224.

(60) Verkerk, R.; Dekker, M.; Jongen, W. M. F. J. Sci. Food Agric. 2001, 81, 953-958.

(61) Andreasson, E.; Jorgensen, L. B.; Hoglund, A. S.; Rask, L.; Meijer, J. Plant Physiol. 2001, $127,1750-1763$.

(62) Husebye, H.; Chadchawan, S.; Winge, P.; Thangstad, O. P.; Bones, A. M. Plant Physiol. 2002, 128, 1180-1188.

(63) Kliebenstein, D. J.; Kroymann, J.; Mitchell-Olds, T. Curr. Opin. Plant Biol. 2005, 8, 264271.

(64) Tripathi, M. K.; Mishra, A. S. Anim. Feed Sci. Technol. 2007, 132, 1-27.

(65) Talalay, P.; Fahey, J. W. J. Nutr. 2001, 131, 3027S-3033S. 
515 (66) Chen, S.; Andreasson, E. Plant Physiol. Biochem. 2001, 39, 743-758.

516 (67) Hoglund, A. S.; Lenman, M.; Falk, A.; Rask, L. Plant Physiol. 1991, 95, 213-221.

517 (68) Getahun, S. M.; Chung, F. L. Cancer Epidemiol. Biomarkers Prev. 1999, 8, 447-451.

518 (69) Fenwick, G. R.; Heaney, R. K. Food Chem. 1983, 11, 249-271.

519 (70) Rabot, S.; Nugonbaudon, L.; Raibaud, P.; Szylit, O. Br. J. Nutr. 1993, 70, 323-331.

520 (71) Shapiro, T. A.; Fahey, J. W.; Wade, K. L.; Stephenson, K. K.; Talalay, P. Cancer Epidemiol. 521

(72) Fahey, J. W.; Zhang, Y. S.; Talalay, P. Proc. Natl. Acad. Sci. U. S. A. 1997, 94, 10367-10372.

523 (73) Heaney, R. K.; Fenwick, G. R. J. Sci. Food Agric. 1980, 31, 593-599.

(74) Kushad, M. M.; Brown, A. F.; Kurilich, A. C.; Juvik, J. A.; Klein, B. P.; Wallig, M. A.; Jeffery, E. H. J. Agric. Food Chem. 1999, 47, 1541-1548.

(75) Rosa, E.; Heaney, R. Anim. Feed Sci. Technol. 1996, 57, 111-127.

(76) Rangkadilok, N.; Nicolas, M. E.; Bennett, R. N.; Premier, R. R.; Eagling, D. R.; Taylor, P. W. J. Sci. Hortic. (Amsterdam). 2002, 96, 11-26.

529 (77) Agerbirk, N.; Olsen, C. E.; Nielsen, J. K. Phytochemistry 2001, 58, 91-100.

530 (78) Coogan, R. C.; Wills, R. B. H.; Nguyen, V. Q. Food Chem. 2001, 72, 1-3.

531 (79) Ahuja, I.; de Vos, R. C. H.; Bones, A. M.; Hall, R. D. Trends Plant Sci. 2010, 15, 664-674.

(80) Hasegawa, T.; Yamada, K.; Kosemura, S.; Yamamura, S.; Hasegawa, K. Phytochemistry 2000, 54, 275-279.

534 (81) Bartlet, E.; Kiddle, G.; Williams, I.; Wallsgrove, R. Entomol. Exp. Appl. 1999, 91, 163-167.

(82) Jin, J.; Koroleva, O. A.; Gibson, T.; Swanston, J.; Magan, J.; Zhang, Y.; Rowland, I. R.; Wagstaff, C. J. Agric. Food Chem. 2009, 57, 5227-5234.

537 (83) Holst, B.; Williamson, G. Nat. Prod. Rep. 2004, 21, 425-447.

538 (84) Stoewsand, G. S. Food Chem. Toxicol. 1995, 33, 537-543.

539 (85) Fahey, J. W.; Zalcmann, A. T.; Talalay, P. Phytochemistry 2001, 56, 5-51.

540 (86) Cartea, M. E.; Francisco, M.; Soengas, P.; Velasco, P. Molecules 2011, 16, 251-280.

541 (87) Zhang, Y. S.; Talalay, P. Cancer Res. 1994, 54, S1976-S1981. 
(88) Rose, P.; Won, Y. K.; Ong, C. N.; Whiteman, M. Nitric Oxide-Biology Chem. 2005, 12, 237243.

(89) Conaway, C. C.; Yang, Y. M.; Chung, F. L. Curr. Drug Metab. 2002, 3, 233-255.

(90) Windsor, A. J.; Reichelt, M.; Figuth, A.; Svatos, A.; Kroymann, J.; Kliebenstein, D. J.; Gershenzon, J.; Mitchell-Olds, T. Phytochemistry 2005, 66, 1321-1333.

(91) Wheat, C. W.; Vogel, H.; Wittstock, U.; Braby, M. F.; Underwood, D.; Mitchell-Olds, T. Proc. Natl. Acad. Sci. U. S. A. 2007, 104, 20427-20431.

(92) Rodman, J. E.; Karol, K. G.; Price, R. A.; Sytsma, K. J. Syst. Bot. 1996, 21, 289-307.

(93) Wittstock, U.; Halkier, B. A. Trends Plant Sci. 2002, 7, 263-270.

(94) Verkerk, R.; Schreiner, M.; Krumbein, A.; Ciska, E.; Holst, B.; Rowland, I.; De Schrijver, R.; Hansen, M.; Gerhauser, C.; Mithen, R.; Dekker, M. Mol. Nutr. Food Res. 2009, 53, S219S265.

(95) Rosa, E. A. S. Phytochemistry 1997, 44, 1415-1419.

(96) Clarke, D. B. Anal. Methods 2010, 2, 310-325.

(97) Mithen, R. F.; Dekker, M.; Verkerk, R.; Rabot, S.; Johnson, I. T. J. Sci. Food Agric. 2000, 80, 967-984.

(98) Charron, C. S.; Saxton, A. M.; Sams, C. E. J. Sci. Food Agric. 2005, 85, 671-681.

(99) Schreiner, M. Eur. J. Nutr. 2005, 44, 85-94.

(100) Schouten, R. E.; Zhang, X. B.; Verkerk, R.; Verschoor, J. A.; Otma, E. C.; Tijskens, L. M. M.; van Kooten, O. Postharvest Biol. Technol. 2009, 53, 1-10.

(101) Graser, G.; Schneider, B.; Oldham, N. J.; Gershenzon, J. Arch. Biochem. Biophys. 2000, 378, 411-419.

(102) Arabbi, P. R.; Genovese, M. I.; Lajolo, F. M. J. Agric. Food Chem. 2004, 52, 1124-1131.

(103) Podsedek, A. Lwt-Food Sci. Technol. 2007, 40, 1-11.

(104) Cartea, M. E.; Velasco, P.; Obregon, S.; Padilla, G.; de Haro, A. Phytochemistry 2008, 69, 403-410.

(105) Salah, N.; Miller, N. J.; Paganga, G.; Tijburg, L.; Bolwell, G. P.; Riceevans, C. Arch. Biochem. Biophys. 1995, 322, 339-346.

(106) Hansen, M.; Laustsen, A. M.; Olsen, C. E.; Poll, L.; Sorensen, H. J. Food Qual. 1997, 20, 441-459. 
(107) Martinez-Sanchez, A.; Allende, A.; Cortes-Galera, Y.; Gil, M. I. Postharvest Biol. Technol. 2008, 47, 382-388.

(108) Schonhof, I.; Krumbein, A.; Bruckner, B. Nahrung-Food 2004, 48, 25-33.

(109) Iori, R.; Bernardi, R.; Gueyrard, D.; Rollin, P.; Polmieri, S. Bioorg. Med. Chem. Lett. 1999, 9, 1047-1048.

(110) Cerny, M. S.; Taube, E.; Battaglia, R. J. Agric. Food Chem. 1996, 44, 3835-3839.

(111) Melchini, A.; Costa, C.; Traka, M.; Miceli, N.; Mithen, R.; De Pasquale, R.; Trovato, A. Food Chem. Toxicol. 2009, 47, 1430-1436.

(112) Leoni, O.; Iori, R.; Palmieri, S.; Esposito, E.; Menegatti, E.; Cortesi, R.; Nastruzzi, C. Bioorg. Med. Chem. 1997, 5, 1799-1806.

(113) Wu, X.; Zhou, Q. H.; Xu, K. Acta Pharmacol. Sin. 2009, 30, 501-512.

(114) Zhu, C. Y.; Loft, S. Food Chem. Toxicol. 2003, 41, 455-462.

(115) Kassie, F.; Rabot, S.; Uhl, M.; Huber, W.; Qin, H. M.; Helma, C.; Schulte-Hermann, R.; Knasmuller, S. Carcinogenesis 2002, 23, 1155-1161.

(116) Alqasoumi, S.; Ai-Sohaibani, M.; Ai-Howiriny, T.; Al-Yahya, M.; Rafatullah, S. World J. Gastroenterol. 2009, 15, 1958-1965.

(117) Hanlon, N.; Coldham, N.; Sauer, M. J.; Ioannides, C. Chem. Biol. Interact. 2009, 177, 115120.

(118) Cole, R. A. Phytochemistry 1976, 15, 759-762.

(119) Matusheski, N. V; Wallig, M. A.; Juvik, J. A.; Klein, B. P.; Kushad, M. M.; Jeffery, E. H. J. Agric. Food Chem. 2001, 49, 1867-1872.

(120) Uda, Y.; Kurata, T.; Arakawa, N. Agric. Biol. Chem. 1986, 50, 2735-2740.

(121) Macleod, A. J.; Rossiter, J. T. Phytochemistry 1986, 25, 1047-1051.

(122) Tookey, H. L.; Wolff, I. A. Can. J. Biochem. 1970, 48, 1024-\&.

(123) Uda, Y.; Kurata, T.; Arakawa, N. Agric. Biol. Chem. 1986, 50, 2741-2746.

(124) Gil, V.; Macleod, A. J. Phytochemistry 1980, 19, 227-231.

(125) Cashman, J. R.; Xiong, Y.; Lin, J.; Verhagen, H.; van Poppel, G.; van Bladeren, P. J.; LarsenSu, S.; Williams, D. E. Biochem. Pharmacol. 1999, 58, 1047-1055.

(126) Graham, S. Cancer Res. 1983, 43, 2409-2413.

(127) Bonnesen, C.; Eggleston, I. M.; Hayes, J. D. Cancer Res. 2001, 61, 6120-6130. 
602

(128) Kim, D. J.; Han, B. S.; Ahn, B.; Hasegawa, R.; Shirai, T.; Ito, N.; Tsuda, H. Carcinogenesis 1997, 18, 377-381.

(129) Wattenberg, L. W.; Loub, W. D. Cancer Res. 1978, 38, 1410-1413.

(130) Bresnick, E.; Birt, D. F.; Wolterman, K.; Wheeler, M.; Markin, R. S. Carcinogenesis 1990, $11,1159-1163$.

(131) Bradlow, H. L.; Michnovicz, J. J.; Telang, N. T.; Osborne, M. P. Carcinogenesis 1991, 12, 1571-1574.

(132) Kojima, T.; Tanaka, T.; Mori, H. Cancer Res. 1994, 54, 1446-1449.

(133) Tanaka, T.; Kojima, T.; Morishita, Y.; Mori, H. Japanese J. Cancer Res. 1992, 83, 835-842.

(134) Tanaka, T.; Mori, Y.; Morishita, Y.; Hara, A.; Ohno, T.; Kojima, T.; Mori, H. Carcinogenesis 1990, 11, 1403-1406.

(135) Kim, D. J.; Lee, K. K.; Han, B. S.; Ahn, B.; Bae, J. H.; Jang, J. J. Japanese J. Cancer Res. 1994, $85,578-583$.

(136) Staack, R.; Kingston, S.; Wallig, M. A.; Jeffery, E. H. Toxicol. Appl. Pharmacol. 1998, 149, $17-23$.

(137) Verhoeven, D. T. H.; Verhagen, H.; Goldbohm, R. A.; vandenBrandt, P. A.; vanPoppel, G. Chem. Biol. Interact. 1997, 103, 79-129.

(138) Wattenberg, L. W. Cancer Res. 1985, 45, 1-8.

(139) Kuang, Y. F.; Chen, Y. H. Food Chem. Toxicol. 2004, 42, 1711-1718.

(140) Gamet-Payrastre, L.; Lumeau, S.; Gasc, N.; Cassar, G.; Rollin, P.; Tulliez, J. Anticancer. Drugs 1998, 9, 141-148.

(141) Ge, X. K.; Fares, F. A.; Yannai, S. Anticancer Res. 1999, 19, 3199-3203.

(142) Cover, C. M.; Hsieh, S. J.; Tran, S. H.; Hallden, G.; Kim, G. S.; Bjeldanes, L. F.; Firestone, G. L. J. Biol. Chem. 1998, 273, 3838-3847.

(143) Sarkar, F. H.; Li, Y. W. J. Nutr. 2004, 134, 3493S-3498S.

(144) Lijang, S.; Iori, R.; Thornalley, P. J. J. Sci. Food Agric. 2006, 86, 1271-1280.

(145) Zhao, D. Y.; Tang, J.; Ding, X. L. Lwt-Food Sci. Technol. 2007, 40, 439-447.

(146) Wink, M. Biochemistry of Plant Secondary Metabolites; Wiley-Blackwell, 2010; Vol. 40.

(147) Greer, M. A. Arch. Biochem. Biophys. 1962, 99, 369-371.

(148) Grubb, C. D.; Gross, H. B.; Chen, D. L.; Abel, S. Plant Sci. 2002, 162, 143-152. 
(149) Ghawi, S. K.; Methven, L.; Niranjan, K. Food Chem. 2013, 138, 1734-1741.

(150) Higdon, J. V; Delage, B.; Williams, D. E.; Dashwood, R. H. Pharmacol. Res. 2007, 55, $224-$ 236.

(151) Mcdanell, R.; Mclean, A. E. M.; Hanley, A. B.; Heaney, R. K.; Fenwick, G. R. Food Chem. Toxicol. 1988, 26, 59-70.

(152) Lanzani, A.; Piana, G.; Piva, G.; Cardillo, M.; Rastelli, A.; Jacini, G. J. Am. Oil Chem. Soc. 1974, 51, 517-518.

(153) Mawson, R.; Heaney, R. K.; Zdunczyk, Z.; Kozlowska, H. Food / Nahrung 1993, 37, 336344.

(154) Dewick, P. M. Medicinal natural products a biosynthetic approach, 2009, 1 online resource $(x, 539$ p.).

(155) Nishie, K.; Daxenbichler, M. E. Food Cosmet. Toxicol. 1980, 18, 159-172.

(156) Fenwick, G. R.; Griffiths, N. M. Zeitschrift fur Leb. und -forsch. 1981, 172, 90-92.

(157) Fenwick, G. R.; Griffiths, N. M.; Heaney, R. K. J. Sci. Food Agric. 1983, 34, 73-80.

(158) Lewis, J.; Fenwick, G. R. Food Chem. 1987, 25, 259-268.

(159) Buskov, S.; Hansen, L. B.; Olsen, C. E.; Sørensen, J. C.; Sørensen, H.; Sørensen, S. J. Agric. Food Chem. 2000, 48, 2693-2701.

(160) Hrncirik, K.; Valusek, J.; Velisek, J. Eur. Food Res. Technol. 2001, 212, 576-581.

(161) Preobrazhenskaya, M. N.; Bukhman, V. M.; Korolev, A. M.; Efimov, S. A. Pharmacol. Ther. 1993, 60, 301-313.

(162) Smith, T. K.; Lund, E. K.; Clarke, R. G.; Bennett, R. N.; Johnson, I. T. J. Agric. Food Chem. 2005, 53, 3895-3901.

(163) Lambrix, V.; Reichelt, M.; Mitchell-Olds, T.; Kliebenstein, D. J.; Gershenzon, J. Plant Cell 2001, 13, 2793-2807.

(164) Hollman, P. C. H.; Katan, M. B. Biomed. Pharmacother. 1997, 51, 305-310.

(165) Hollman, P. C. H.; Katan, M. B. Food Chem. Toxicol. 1999, 37, 937-942.

(166) Harborne, J. B.; Williams, C. A. Phytochemistry 2000, 55, 481-504.

(167) Olsson, L. C.; Veit, M.; Weissenbock, G.; Bornman, J. F. Phytochemistry 1998, 49, 10211028.

(168) Manach, C.; Scalbert, A.; Morand, C.; Remesy, C.; Jimenez, L. Am. J. Clin. Nutr. 2004, 79, 727-747. 
663

664

665

666

667

668

669

670

671

672

673

674

675

676

677

678

679

680

681

682

683

684

685

686

687

688

689

690

691

(169) Kroon, P. A.; Clifford, M. N.; Crozier, A.; Day, A. J.; Donovan, J. L.; Manach, C.; Williamson, G. Am. J. Clin. Nutr. 2004, 80, 15-21.

(170) Engelen-Eigles, G.; Holden, G.; Cohen, J. D.; Gardner, G. J. Agric. Food Chem. 2006, 54, 328-334.

(171) Palaniswamy, U.; McAvoy, R.; Bible, B. Hortscience 1997, 32, 222-223.

(172) Aires, A.; Rosa, E.; Carvalho, R. J. Sci. Food Agric. 2006, 86, 1512-1516.

(173) Palaniswamy, U.; McAvoy, R.; Bible, B.; Singha, S.; Hill, D. Phytochem. Heal. 1995, 15, 280-283.

(174) Koukounaras, A.; Siomos, A. S.; Sfakiotakis, E. J. Food Qual. 2010, 33, 768-779.

(175) Koukounaras, A.; Siomos, A. S.; Sfakiotakis, E. Postharvest Biol. Technol. 2006, 41, 109_ 111.

(176) Howard, L. A.; Jeffery, E. H.; Wallig, M. A.; Klein, B. P. J. Food Sci. 1997, 62, 1098-+.

(177) Kassie, F.; Parzefall, W.; Musk, S.; Johnson, I.; Lamprecht, G.; Sontag, G.; Knasmuller, S. Chem. Biol. Interact. 1996, 102, 1-16.

(178) Rochfort, S. J.; Trenerry, V. C.; Imsic, M.; Panozzo, J.; Jones, R. Phytochemistry 2008, 69, 1671-1679.

(179) Faulkner, K.; Mithen, R.; Williamson, G. Carcinogenesis 1998, 19, 605-609.

(180) Xu, Y. Molecular Plant Breeding; CABI, 2010.

(181) Bozokalfa, M. K.; Yagmur, B.; Ilbi, H.; Esiyok, D.; Kavak, S. Crop Breed. Appl. Biotechnol. 2009, 9, 372-381.

(182) Li, G.; Quiros, C. F. Theor. Appl. Genet. 2001, 103, 455-461.

(183) Baird, N. A.; Etter, P. D.; Atwood, T. S.; Currey, M. C.; Shiver, A. L.; Lewis, Z. A.; Selker, E. U.; Cresko, W. A.; Johnson, E. A. PLoS One 2008, 3.

(184) Glenn, T. C. Mol. Ecol. Resour. 2011, 11, 759-769.

(185) Hall, C.; McCallum, D.; Prescott, A.; Mithen, R. Theor. Appl. Genet. 2001, 102, 369-374.

(186) Lelario, F.; Bianco, G.; Bufo, S. A.; Cataldi, T. R. I. Phytochemistry 2012, 73, 74-83.

(187) Botting, C. H.; Davidson, N. E.; Griffiths, D. W.; Bennett, R. N.; Botting, N. P. J. Agric. Food Chem. 2002, 50, 983-988.

(188) Kim, S. J.; Ishii, G. Soil Sci. Plant Nutr. 2006, 52, 394-400. 
692 (189) Villatoro-Pulido, M.; Priego-Capote, F.; Alvarez-Snachez, B.; Saha, S.; Philo, M.; Obregon693 Cano, S.; De Haro-Bailon, A.; Font, R.; Del Rio-Celestino, M. J. Sci. Food Agric. 2013.

694

695 Acknowledgement of funding support

696 Luke Bell is supported by BBSRC Case Award (Reference BB/J012629/1) in partnership with 697 Elsoms Seeds Ltd. (Spalding, UK) and Bakkavor Group Ltd. (Spalding, UK). 


\section{Figure captions}

Figure 1: - The glucosinolate-myrosinase reaction and some of the subsequent compounds produced under different conditions, such as $\mathrm{pH}$ and the influence of epithiospecifier proteins (ESP) (Adapted from Zhang ${ }^{9}$ and Hall et al. ${ }^{185}$ ).

Figure 2: - Pathways of documented ITC action in tumorigenic cells. See Wu et al. ${ }^{113}$ for a detailed review of the roles ITCs play in cancer prevention.

Figure 3: - The mercapturic acid pathway of ITC metabolism in the human body. After ingestion of rocket leaves glucoerucin is hydrolyzed by myrosinase to form erucin. This is released and absorbed in the ileum, where it is transported in the blood to cells around the body. ITCs initiate Phase II detoxification enzymes in this pathway, and are known to aid in cancer prevention. (Adapted from Wu et al. ${ }^{113}$ ).

Figure 4: - Factors and conditions within the commercial supply chain that affect GSL and flavonol levels within rocket leaves. 


\begin{tabular}{|c|c|c|c|c|c|}
\hline R-group & Common name & R-group structure $x$ & $\begin{array}{l}\text { Mass parent } \\
\text { ion }\end{array}$ & $\begin{array}{l}\text { MS }^{2} \text { spectrum ions } \\
\text { (signature ions in } \\
\text { bold) }\end{array}$ & Reference \\
\hline 2-(benzoyloxy) ethyl & - & & 466 & 386 & 33 \\
\hline $\begin{array}{c}\text { 3-hydroxy-5-(methylsulfinyl) } \\
\text { pentyl }\end{array}$ & - & & 482 & 403 & \\
\hline $\begin{array}{l}\text { 4-( } \beta \text {-D-glucopyranosyldisulfanyl) } \\
\text { butyl }\end{array}$ & Diglucothiobeinin & & 600 & 521 & 33,186 \\
\hline 5-(methylsulfinyl) pentyl & Glucoalyssin & & 450 & 371 & \\
\hline$N$-butyl & Dihydrogluconapin & & 374 & 294 & \\
\hline 4-phenylbutyl & Glucoamoracin & & 450 & 371 & 28 \\
\hline 7-(methylsulfinyl) heptyl & Glucoibarin & & 494 & 414 & \\
\hline Ethyl & Glucolepiidin & & 346 & 266 & \\
\hline
\end{tabular}


2-phenylethyl

Gluconasturtiin

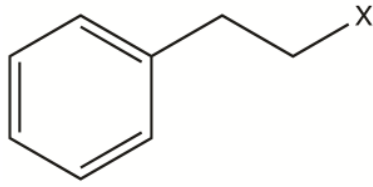

4-(methylsulfinyl)-3-butenyl

Dimeric 4-mercaptobutyl

4-mercaptobutyl

4-hydroxy-3-indolymethyl

4-(methylthio) butyl

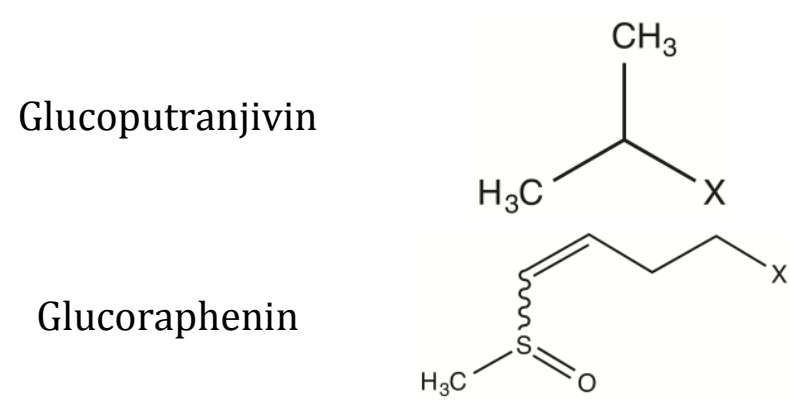

DMB

Glucosativin

4-

Hydroxyglucobrassicin
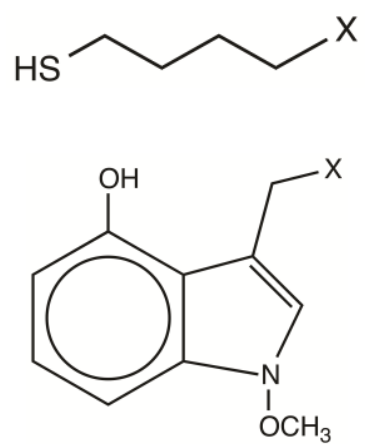

Glucoerucin
422

406

343

28

360

434

354

811

731, 569, 405

$21,33,186$

259, 209, 194, 138

97, 96

463

$383,285,275,267$, 259, 240

33,178

$340,291,275,259$

420
242, 227, 195, 178,

163 


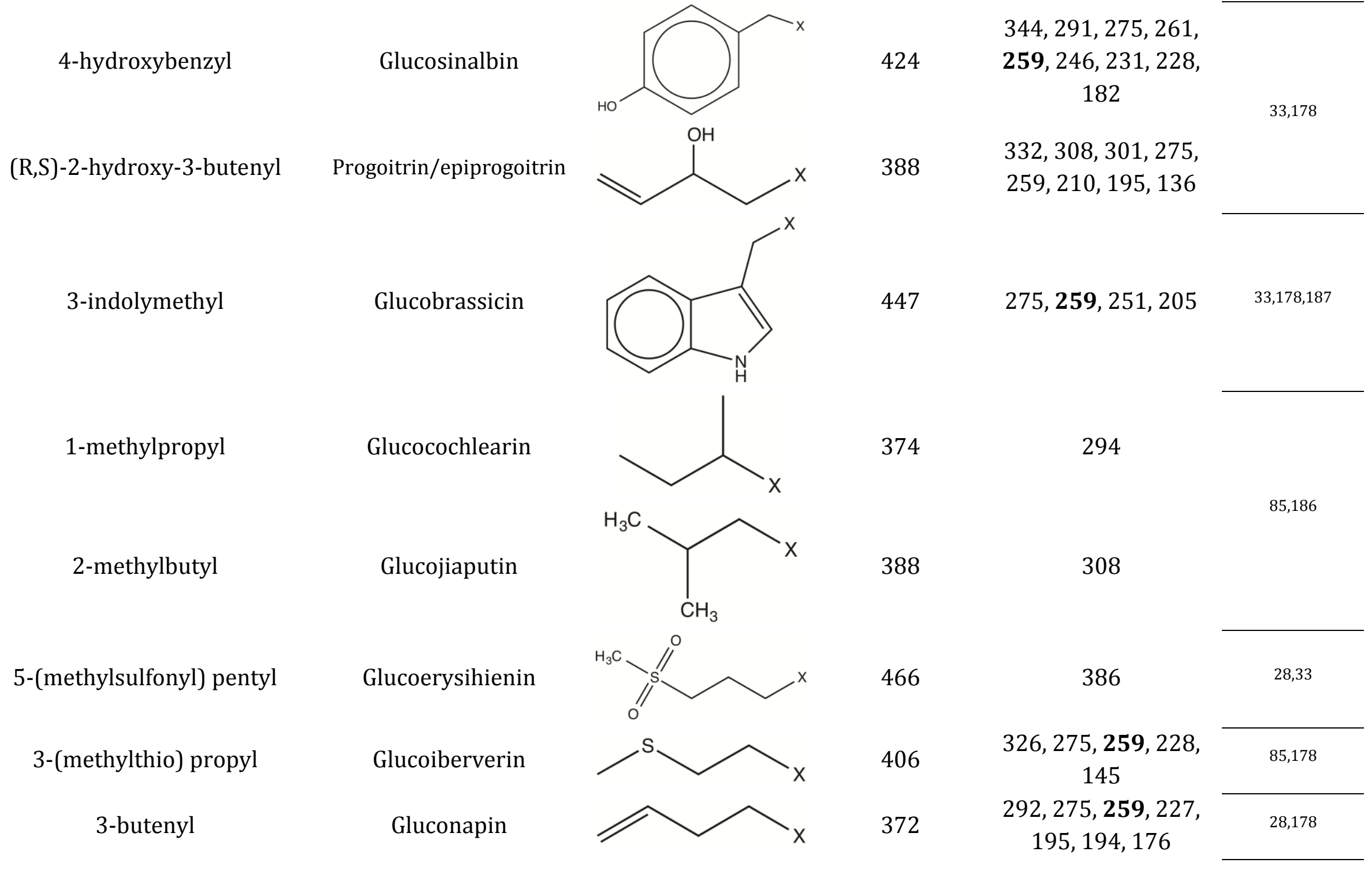




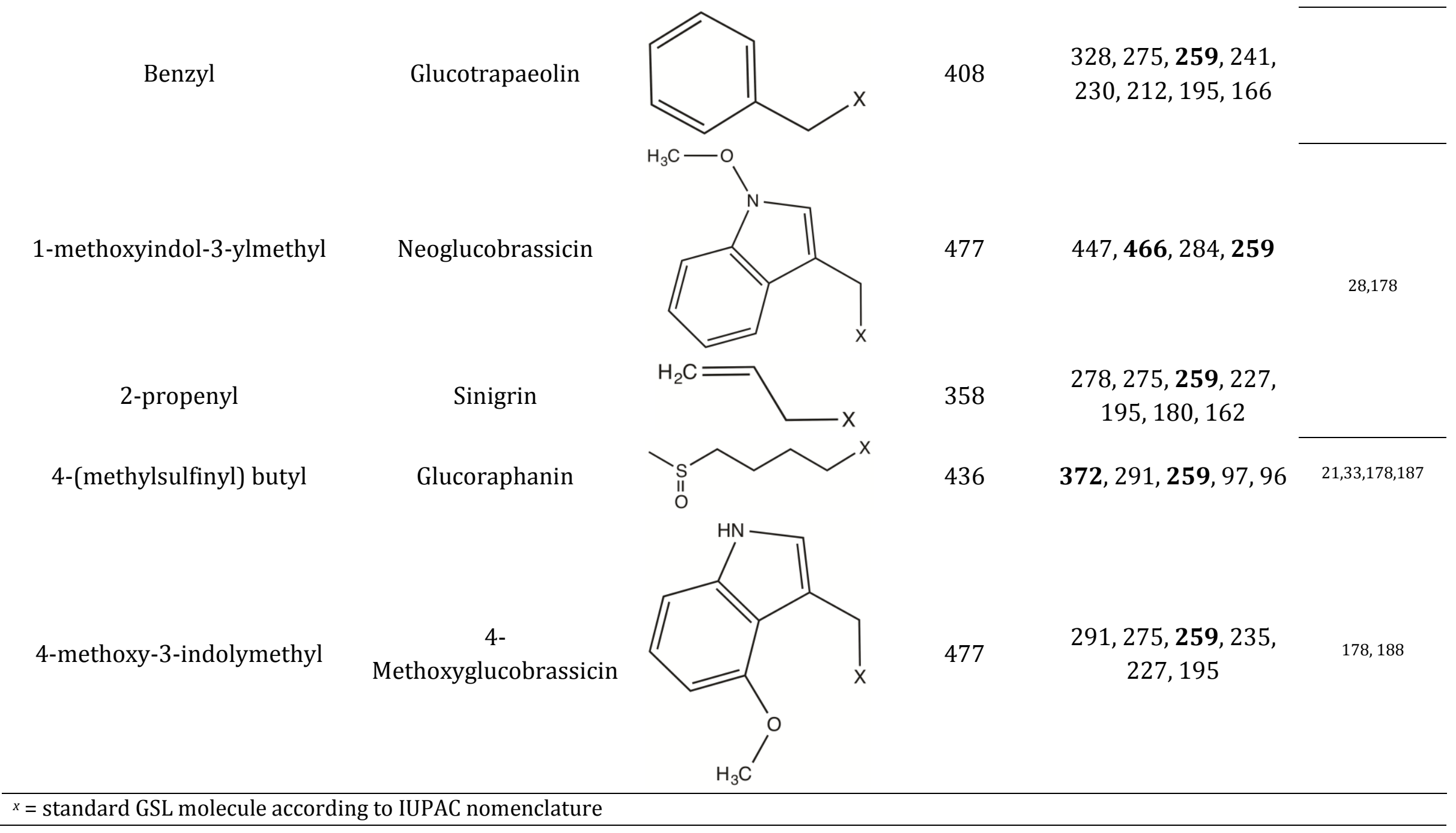




\begin{tabular}{|c|c|c|c|c|c|}
\hline Flavonol compound $a$ & $\operatorname{Eruca}^{p}$ & Diplotaxis $p$ & $\begin{array}{c}\text { Mass } \\
\text { parent ion }\end{array}$ & $\begin{array}{c}\text { MS }^{2} \text { spectrum ions } \\
\text { (signature ion in bold) }\end{array}$ & Reference \\
\hline I 3,4'-diGlc & $\checkmark$ & $\checkmark$ & 639 & 477 & \multirow{6}{*}{18,33} \\
\hline I 3-Glc & $\checkmark$ & & 477 & - & \\
\hline K 3-(2-Sinp-Glc)-4'-Glc & $\checkmark$ & & 817 & - & \\
\hline K 3,4'-diGlc & $\checkmark$ & $\checkmark$ & 609 & - & \\
\hline K 3-Glc & $\checkmark$ & & 447 & 285 & \\
\hline Q 3-Glc & $\checkmark$ & & 463 & 301 & \\
\hline K 3-diGlc-7-Glc & $\checkmark$ & & 771 & 609 & \multirow{3}{*}{33} \\
\hline K 3-Sinp-triGlc-7-Glc & $\checkmark$ & & 1139 & $977,771,609,429$ & \\
\hline Q 3,4'-diGlc-3'-(6-Caf-Glc) & & $\checkmark$ & 949 & $787,625,463,301$ & \\
\hline M & $\checkmark$ & & 317 & 151 & \multirow{3}{*}{189} \\
\hline Q & $\checkmark$ & & 301 & 151 & \\
\hline $\mathrm{R}$ & $\checkmark$ & & 609 & 300 & \\
\hline Q 3-(2-Caf-Glc)-3'-(6-Sinp-Glc)-4'-Glc & & $\checkmark$ & 1155 & $\begin{array}{c}993,831,787,669,625 \\
463,301\end{array}$ & \multirow[t]{2}{*}{18,25} \\
\hline Q 3-(2-Mcaf-Glc)-3'-(6-Sinp-Glc)-4'-Glc & & $\checkmark$ & 1185 & $1023,817,669,655$ & \\
\hline Q 3-(2-Fer-Glc)-3'-(6-Fer-Glc)-4'-Glc & & $\checkmark$ & 1139 & $977,639,463$ & \\
\hline Q 3-(2-Fer-Glc)-3'-(6-Sinp-Glc)-4'-Glc & & $\checkmark$ & 1169 & $\begin{array}{c}1007,831,669,639,463 \\
301\end{array}$ & $18,25,33$ \\
\hline
\end{tabular}




\begin{tabular}{llcc} 
Q 3-(2-Sinp-Glc)-3'-(6-Sinp-Glc)-4'-Glc & $\checkmark$ & 1199 & $1037,831,669,463,301$ \\
Q 3,3',4-triGlc & $\checkmark$ & 787 & $625,463,301$ \\
Q 3,4'-diGlc-3'-(6-Fer-Glc) & $\checkmark$ & 963 & $801,639,463,301$ \\
Q 3,4'-diGlc-3'-(6-Mcaf-Glc) & $\checkmark$ & 979 & $817,655,463,301$ \\
Q 3,4'-diGlc-3'-(6- $p$.Coum-Glc) & $\checkmark$ & 933 & $771,609,463,301$ \\
Q 3,4'-diGlc-3'-(6-Sinap-Glc) & $\checkmark$ & 993 & $831,669,463,301$ \\
\hline$a=$ Abbreviations: Caf, caffeyol; Mcaf, methoxycaffeyol; $p$.Coum, $p$-coumaroyl; Fer, feruloyl; Sinp, sinapoyl; Glc, glucoside; \\
$\begin{array}{l}\text { Q, quercetin; K, kaempferol; I, isorhamnetin; M, myricetin; R, rutin } \\
p=\checkmark \text { compound positively identified in species }\end{array}$ \\
\hline
\end{tabular}




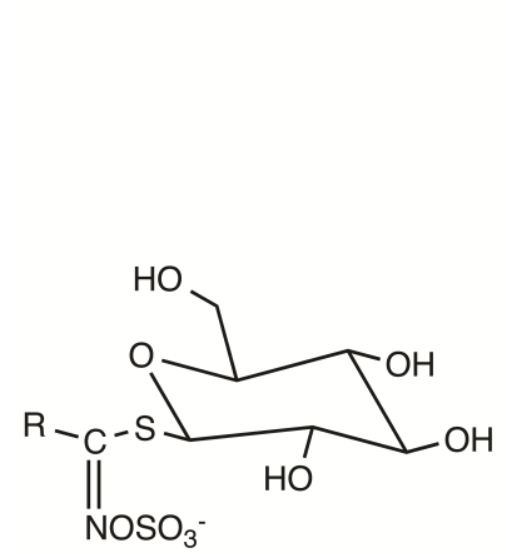

Glucosinolate

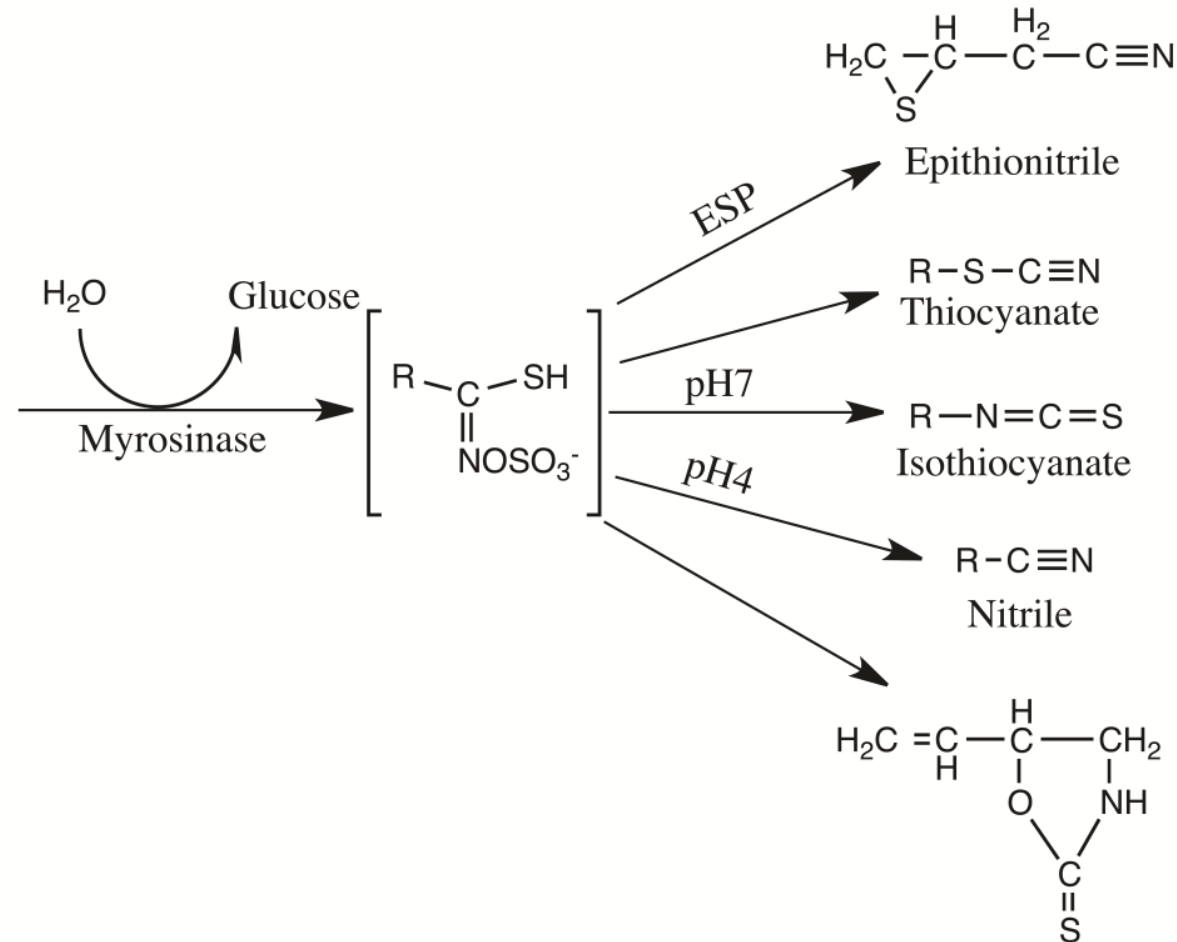

Oxazolidine-thione 


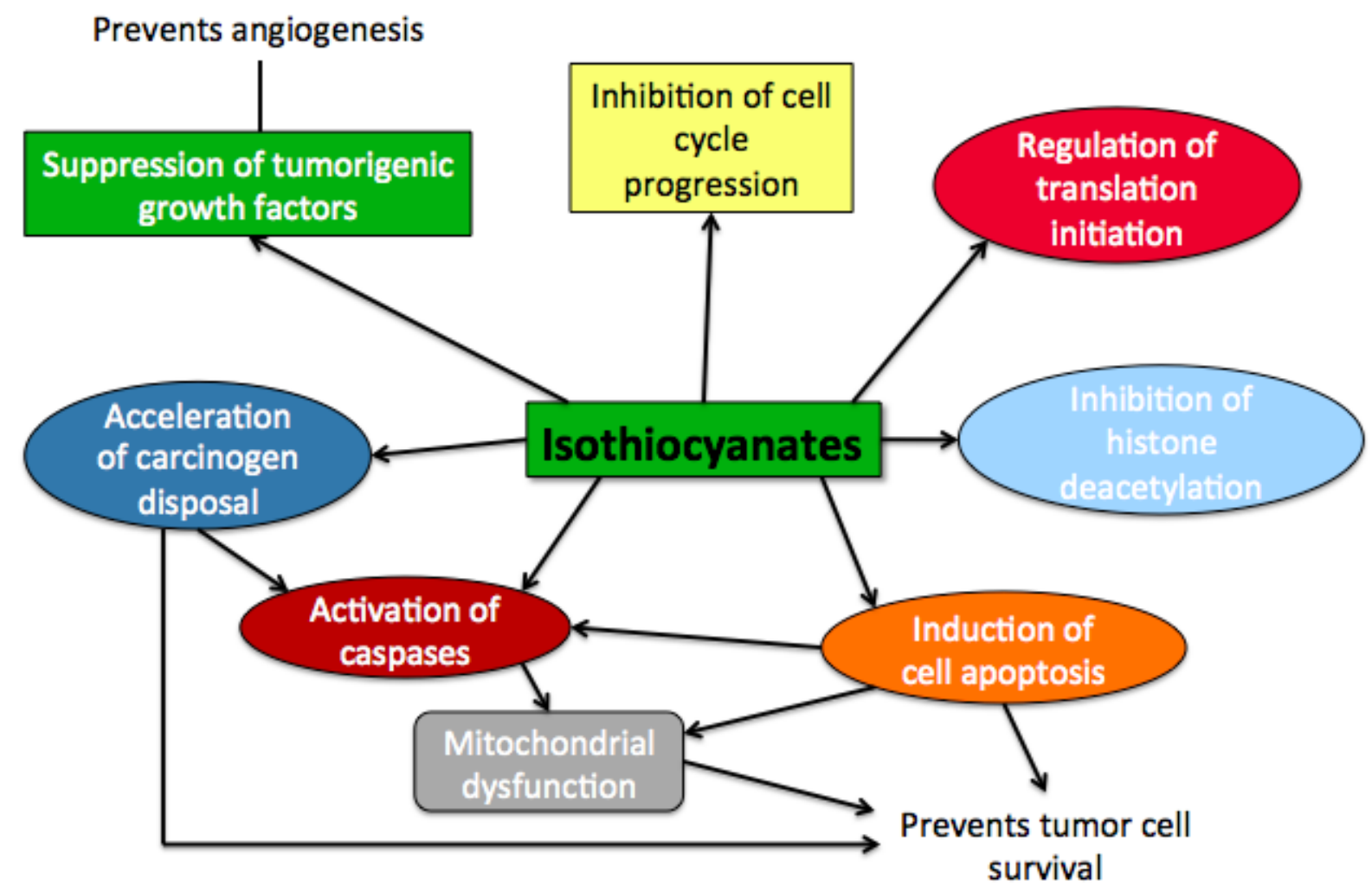




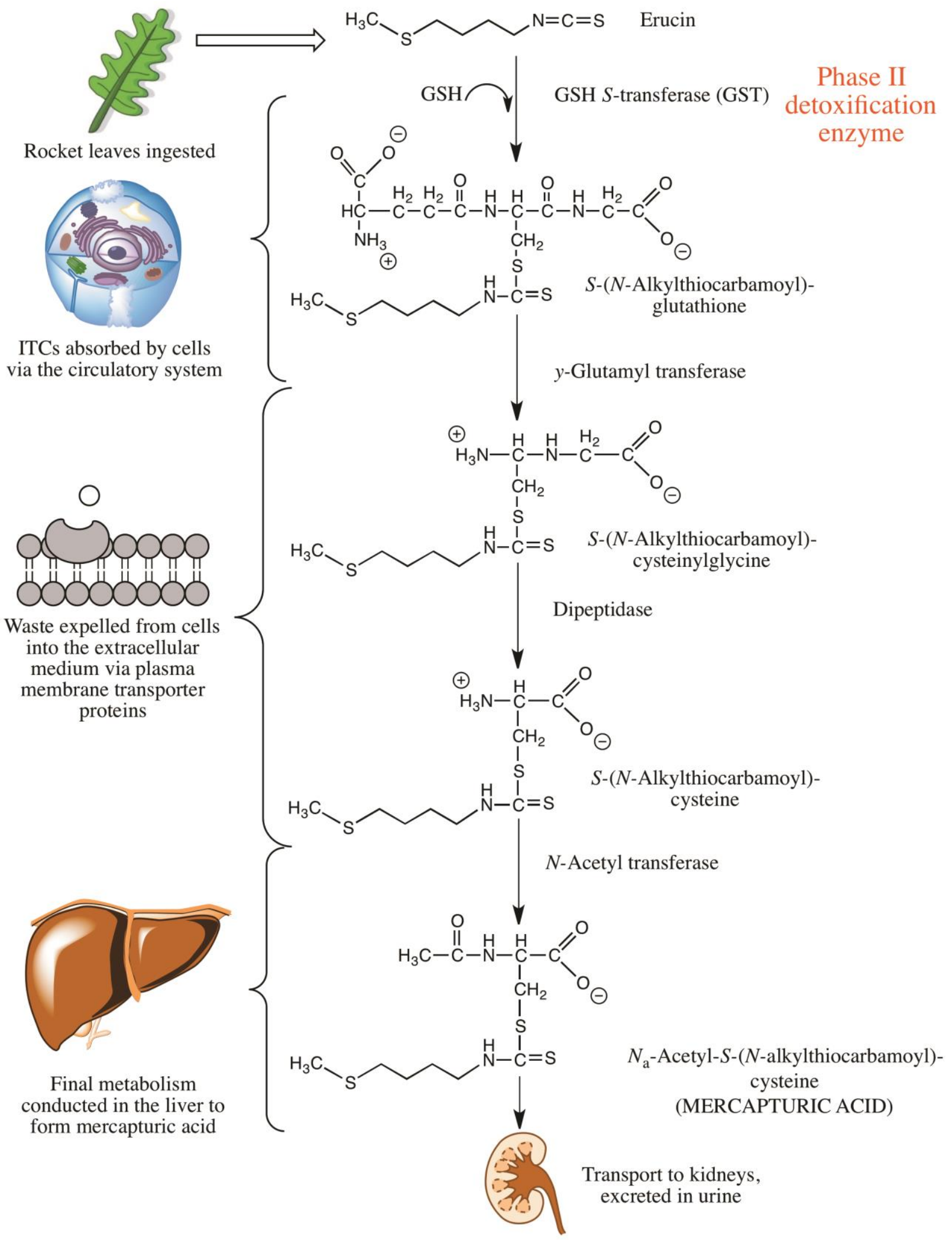




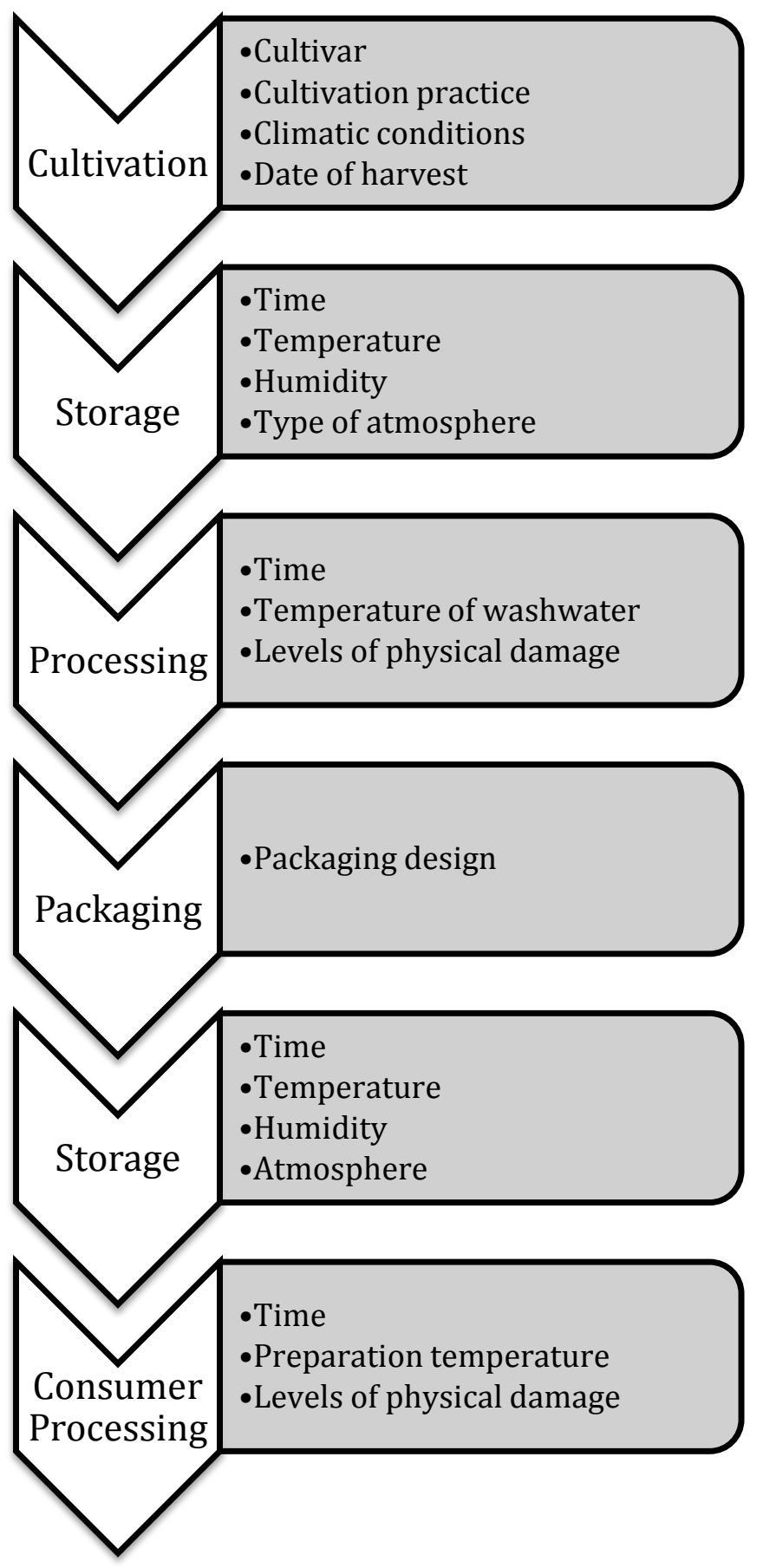




\section{For table of contents only}

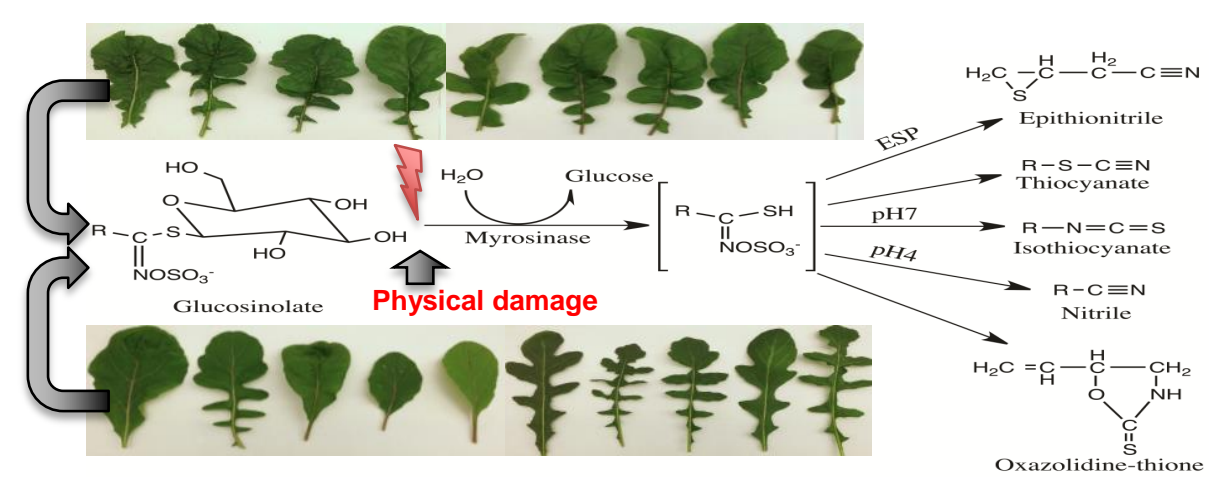

